DOI: $10.17516 / 1997-1370-0602$

УДК 304.444

\title{
Value Orientations in Musical Folklore Peculiar for the Indigenous Minorities of Krasnoyarsk Krai: Research Overview
}

\author{
Svetlana V. Bereziuk and Mikhail la. Khrebtov* \\ Siberian Federal University \\ Krasnoyarsk, Russian Federation
}

Received 03.07.2019, received in revised form 06.09.2019, accepted 21.10.2019

\begin{abstract}
The article presents the results of the musical folklore analysis from the perspective of cultural knowledge. The analysis is aimed to determine value orientations in the course of the musical folklore phenomenon comprehension. The comparative and typological research methods are applied for an analytical overview of this issue. The conducted analysis has resulted in the conclusions about the peculiar features of musical folklore in its historical and cultural development. The main purpose of the considered phenomenon in its value orientation has been revealed. It is claimed that musical folklore is one of the areas of musical art. It has its own spiritual space and displays some features of cultural knowledge. The obtained data can be used for further research of the peoples from other regions of Russia.
\end{abstract}

Keywords: musical folklore, value orientation, values, society, people, culture, ethnos.

The reported study was funded by RFBR, project No. 19-39-90016. The reported study was funded by RFBR, project No. 19-39-90017.

Research area: culturology.

Citation: Bereziuk, S.V., Khrebtov, M.Ia. (2020). Value orientations in musical folklore peculiar for the indigenous minorities of Krasnoyarsk Krai: research overview. J. Sib. Fed. Univ. Humanit. Soc. Sci., 13(5), 728-737. DOI: 10.17516/1997-1370-0602.

\footnotetext{
(C) Siberian Federal University. All rights reserved

* Corresponding author E-mail address: svet2303@mail.ru,khrebtov.m@mail.ru ORCID: 0000-0001-5180-1682 (Bereziuk)
} 


\section{Introduction}

Musical folklore reflects the way of the people's life, their cultural values, views on moral, ethical and aesthetic ideals, as well as their attitude towards society as a whole. The value of folk music is in its truthfulness and depth of text content, expressiveness of its form. Folk songs are focused on a human who embodies the ideal of the people with their best qualities. Besides, musical folklore contributes to the generations' ideological education. The lyrics is semantically oriented, whereas the music is emotionally loaded, thus, complementing the impact of the word on the listener.

The analysis of value orientations in musical folklore of the indigenous minorities of Krasnoyarsk Krai reveals certain regularity between the peculiar features of the musical language and the people's traditional song culture. In addition, the study of the concept of "values" makes the people's self-determination in modern cultural space clear.

The research of musical folklore of Siberian peoples grasped the attention of ethnographers and professional musicians of the $20^{\text {th }}-21^{\text {st }}$ centuries for more than a decade. The issues of musical folklore of the indigenous minorities are covered in the works by L.Ia. Sternberg (1936), I.M. Suslov (1928), G.M. Vasilevich (1969), V.N. Dobrovolskii (1903), A.F. Middendorf (1965), M.G. Voskoboinikov (1980), Iu.I. Sheikin (2002) et al.

The rarest examples of the indigenous minorities' folk music are collected in the works by A. Middendorf, I.M. Suslov, A. M. Eisenstadt (Eisenstadt, 1995), E.V. Hippius (Hippius, 2003).

Overview of the study of folklore of the indigenous peoples of the North is given in the articles by Yu.N. Avdeeva and her co-authors (2019a, 2019b), M.A. Kolesnik (2014), M.A. Kolesnik and the co-authors (2018), N.P. Koptseva (2014), V.N. Ivanov (2013), K.I. Shimansky and N.P. Koptseva (2014), Yu.S. Zamaraeva and her co-authors (2019), A.V. Kistova and the co-authors (2019), N.N. Nevolko (2011), K.V. Reznikova and her co-authors (2019), N.M. Libakova and E.A. Sertakova (2018), N.M. Libakova and her co-authors (2017), et al.
Field researches of musical folklore of Krasnoyarsk Krai of the last decade are described in the articles by L.D. Eckard (2012), M.M. Chikhacheva (2018), G.S. Vinogradov (2009) et al.

The value aspect is viewed in the works by M.K. Petrov (2004), V.E. Davidovich (2013), Iu.A. Zhdanov (2005), G.V. Drach (2003), E.Ia. Rezhabek (2002), V. P. Filatov (1989), O.M. Shtompel (2009), S.N. Iaremenko (1997), T. P. Mates (2016), S. Ia. Podoprigora (2015), M.V. Zakovorotnaia (1999) et al.

This overview proves the relevance of the musical folklore research and its values as well as the interest it arises in the course of years, the key focus being on the musical language of traditional songs and on the semantic content of the text. Yet, the elements of musical folklore are still poorly understood.

\section{Methodology}

The specificity of musical folklore is in studying the elements of musical culture, rituals, and rites as autonomous definitions as well as in their interpenetration. The indigenous minorities' traditional folklore displays interpenetration of these elements. The main method of studying this phenomenon is that of the "structural" analysis of musical folklore works. The methodology of the "comparative" and "functional" analysis can also be applied in order to clearly analyze the melody of songs, as well as their poetic texts.

The structural and typological method in the study of rites reveals the systemic relations within the ritual tradition. Thus, it provides with the material for considering the relationship between the rite and the folklore.

Analyzing the features of musical folklore, V.A. Lapin wrote about the musical folklore methods. In particular, the scholar considered the possibility of historical study of this phenomenon. In addition, he put forward the idea of a comparative study of local traditions, as well as of their typological continuity of development.

The combination of musical-analytical and sociological methods makes it possible to identify the features of solo and ensemble singing as well as to determine the type of the sing- 
ers performing in this ethnic group under the conditions of following the traditions.

When studying musical folklore, it is also necessary to consider the verses as per the types of musical-and-song rhythms in their dialectical and historical aspects.

\section{Value orientations peculiar for musical folklore}

The concept of "values" is a key one in defining human society. Values are crucial in a human's life orientation; they are also vital for maintaining social order.

Philosophers had been turning to the comprehension of values for centuries. For example, according to Schopenhauer (1969), the main value is the search for the meaning of life. In his argument, the philosopher emphasizes everyone's personal happiness. He introduced the concept of "will". The purpose of "will" is to continue the human race, but not to make the individual happy. A person can never be happy, since happiness cannot last for a long time in the present. Schopenhauer believes that happiness is always in the unknown future or in the past.

In his time, Wilhelm Dilthey (1980) approached the structure of the subjective value system through the process of personal development. He considered this process as an alternation of certain states of life. A certain structure of subjective values is characteristic for each state of life. Hence, according to Dilthey, the individual's development is "the transition of the individual from one system of subjective values to another system of higher life values".

It is from the position of the cultural-historical relativism that Jean Baudrillard (2008) models the scheme of evolutionary-historical development of values. This scheme consists of the so-called "three orders of simulacra" of the individual's development, alternating from the Renaissance to the present day. Baudrillard paid attention to the role of value variability in each order of simulacra.

J. Habermas (1992) raises the issue of value variability in relation to the spiritual sphere of society. He conditionally divided all values into two groups. The first category includes ethical values that contribute to the individ- uals' and communities' self-identification, the second group embraces moral values that display a universal character. Following and developing I. Kant's ideas, Habermas distinguishes ethical, pragmatic and moral spheres of practical reason application. The ethical sphere covers the issues of self-knowledge of values as well as self-determination of an individual in his/her space of values. The pragmatic one includes human actions or deeds that can be accepted as a general law for everyone.

The moral sphere manifests itself in the form of norms, which in this case are applied as a duty and are objective in nature, i.e. do not depend on subjective consciousness. As a result, Habermas in his time determined the peculiarities of the development of culture, science, technology and all human activities, and namely, internationalization of cultural life, demonstration of power, power of technology, and human mind. It is this background against which revaluation of values and a change of philosophical paradigms took place in the context of a contradictory cultural situation in philosophy.

G. Rickert (1998) analyzed the values as an ideal and reference point for sociocultural development of society, which also forms social motivations of individuals and society as a whole. As a result of value awareness people form certain attitudes peculiar for their daily activities.

Regarding the issue of values, P. Sorokin claims that "the value is the basis of all cultures. Each culture has its own axiological core. Depending on a dominant value, this core divides all cultural super-systems into ideational (the predominance of spiritual values), sensory (the predominance of sensory-empirical perception of reality), and idealistic (the synthesis of the first two types)" (Sorokin, 1992).

The central link in value orientation is a human, his/her life and development. A person who is able to foresee the consequences of his/ her actions will not prevent deviations from the balanced development of the "man - society nature" system.

Value orientation of musical folklore, developed by the scholars, ethnographers, and 
folklorists for many years, gives a clue to the nature of values as an important component and regulator of the activity of the individual and the society. This allows us to establish the place of cultural values, social ideals and personal orientations in human behavior.

Such values as humanism, taking care of each other, respect for the elders, politeness, justice, etc. are conveyed in the song tradition through the text and music. From year to year, beautiful songs, tools and traditional clothing have been created. The beauty of the native land is hymned in traditional songs of the indigenous minorities of Siberia. Their love is shown not only in words, but also in action. Every word that sounds in their traditional songs is deeply felt and internally meaningful. "The beautiful is not an end in itself; it is an integral part of the people's life" (Volkov, 1976)

The moral and ideological values of traditional music in musical folklore are closely linked. The ideas underlying traditional songs are complemented by the moral ideals of each nation. The ability to approach music from the position of moral and ethical qualities characterizes the individual's true musical culture.

Acquisition of value orientations in society is primarily associated with mastering the generations' spiritual heritage and with a careful attitude to folk traditions of the region where one or another ethnic group lives.

Considering the traditional values of folk music, Z.Z. Krymguzhina claims: "Only by assimilating national values one can understand the ideals of other times, peoples, and the world. Human values are not reduced to the sum of accumulated material and spiritual values only; they imply the formation of the new generations' ability to create new values, new systems of relations" (Krymguzhina, 2017).

The formation of ethno-cultural orientations consists of value actualization. The key feature of folklore is the unity of music and movement in it, which favours the perception of all its elements. A person's musical consciousness formation, in its turn, is a result of the impact of mass musical culture he/she is currently in.

Siberia is diverse and rich in both its beauty, the originality of nature, and the cultural values of the peoples living here. Each nation has its own culture and customs, as well as music with its own distinctive elements and tools. A human with his/her inner world and value orientation is the subject of the research. It is owing to values, that a certain way of thinking is formed in a human's mind and, thus, helps them in their way of life and their own understanding of their life path.

\section{Peculiar features of musical folklore}

Folklore is a certain type of art reflecting the specific components of the people's culture. It can be regarded as the foundation of the entire artistic culture, an original layer in the culture of the society. Considering the phenomenon from this perspective, it can be stated that folklore is one of the oldest strata of a particular people's culture. It unites the culture of the society as per certain ethnic components at a certain period of its historical development. Besides, any folklore piece of art is bifunctional in nature, since it has an aesthetic, utilitarian and applied function.

Musical folklore is one of the main examples of the Humanities. It can be considered not only as a phenomenon of the people's material and spiritual culture, but also as a universal history in general. Regularities in its development, processes and relationships determine the main functions of culture as a whole.

The research of this phenomenon is primarily related to the research of customs, myths, and rituals, as it is an integral part of musical folklore. In addition, the main subject of the analysis is its psychological component. This direction is reflected in C. Jung's and G. Roheim's works. According to the first scholar's conclusions, the collective unconscious serves a sort of the foundation for a human's spiritual life, since it is the result of generic life by itself while being transmitted from generation to generation (Jung, 1991).

The works by the Russian authors are of particular importance in the research of folk tradition. As a system-forming element of culture, it is given the focus of analysis from the 60 s of the $20^{\text {th }}$ century by N.S. Zlobin (1980) and E.V. Sokolov (2010). 
Based on the mentioned above, it can be argued that the study of musical folklore begins from the origins of philosophical knowledge and continues till modern research. The theoretical direction in this study is represented by the information and semiotic cultural analysis. The subject field in cognizing the facts and phenomena of musical folklore is their cross-cultural connection.

The indigenous minorities of Siberia (the Evenks, the Dolgans, the Selkups and the Nganasans, in particular) have established a specific unique form of their living environment in their historical development. Considering the cultural values of the indigenous minorities of Siberia, one can state that it is homogeneous in nature. Most of them have similar life, norms, customs, and spiritual and moral values.

These peoples' system of value orientations was formed under the influence of harsh climatic conditions. Besides, the territory of their residence was also of great importance for their cultural development. All this is reflected in their folklore, rituals, traditional holidays, and a harmonious contact with nature.

The indigenous minorities' folklore reflects ancient archetypal stories, which can contribute to tracing the evolution of culture and their interaction with each other. The ceremonial sphere is of particular significance for the Siberian peoples' traditional culture. It somehow displays customs, peculiar features of holidays, rituals, etc. One of the important elements of their culture is musical folklore, expressed in traditional songs.

Musical folklore of Siberian indigenous minorities is a socio-cultural phenomenon with its own traditional way of manifestation. Each intonation and word carries the deepest meaning in spiritual and creative practice. In the traditional musical culture of Siberian indigenous minorities there is interpenetration, a mixture of elements, genres, and stylistic features that form their own peculiar cultural layer.

The key feature of Siberian musical folklore is its heterogeneity, determined by social and natural factors. The genre composition of Russian musical folklore is quite diverse: calendar and agricultural cycle, song lyrics, epics, ritual songs, etc.
The cultural heritage of Siberia is a real historical treasure trove, represented by grand epic paintings, philosophically deep mythology and endangered languages, picturesque rites and exotic ceremonies. Passing through various stages of its development, the musical folklore of Siberian indigenous minorities has been formed over many centuries.

Their song culture is characterized by the diversity of themes, as well as by characteristic regional musical features. So, for example, when performed in different areas the same song acquires a peculiar, intonation-new sound.

In the traditional folklore of Siberian indigenous minorities the predominance of song culture is great. As a rule, the songs give extremely detailed descriptions of the objects encountered on the way; they describe clothing (one's own and someone else's), a boat, a forest, the habits of animals, etc. Images of nature predominate over personal feelings and experiences. It is especially true for old songs. Nature is very often ensouled. This is primarily due to the psychology of the tribal system. Many songs are associated with fishing, since hunting and fishing were the main types of occupation, and, thus, the people's lives often depended on luck or failure in these activities.

The songs widely reflect life and various customs. A significant place is given to lyrical and humorous songs. At the beginning of the $20^{\text {th }}$ century, there appear songs on social, domestic and political themes. Labor and historical songs are quite rare. This is due to several reasons: firstly, hunting and fishing require complete silence, and, secondly, historical songs were usually not cultivated in improvisational folklore, thus becoming part of oral folk art.

For a long time, songs had no musical notation; they were passed from mouth to mouth. In this regard, the same song may sound different in different regions or even in different courtyards. All possible invocations, lullabies, funeral and wedding songs were improvisational: new melodic-and-rhythmic and poetic variations were introduced at each performance. Yet, over time the most expressive songs got fixed and improved. As a result of natural ex- 
pansion of ancestral ties, the boundaries of the distribution of folklore common for these peoples also expanded, the folklore gradually becoming more stable.

In addition, there appear songs that differ from humming-improvisation. These are specific musical samples with stable fret and structural features. Whereas the information that is fixed can exist for a certain time independently of human consciousness, oral-visual traditions necessarily assume their preservation in the people's memory.

Before the Great October Revolution, the musical culture of the peoples of the North was hardly studied. In the course of the post-revolutionary period, Soviet composers, musicologists and ethnographers began to study them seriously. Special interest in traditional music of the indigenous minorities of Siberia arises only in the second half of the $20^{\text {th }}$ century. Since that time, the systematic study of folklore as a special scientific category begins. Tradition, in its turn, is expressed as a kind of social and group experience. Moreover, it is necessary to distinguish between traditions transmitted by oral folk art or as a result of using the observation method and then recording this material in writing. Whereas fixed information can exist for a certain time independently of human consciousness, oral-visual traditions necessarily assume their preservation in the people's memory. Regarding the tradition, I. Zemtsovskii stated that "traditional nature concerns everything in folklore, without exception, from a special way of thinking, a worldview that is not subject to fashion, a special point of view on life and history... to the manner of sound extraction" (Zemtsovskii, 1978).
In his comparative-historical analysis of cultural features of folklore of the indigenous minorities of Siberia Iu.I. Sheikin (2002) distinguishes its following types:

Traditional folklore is associated with social and psychological mechanisms of social consciousness, which are traced in songs, hymns, and chants.

Archaic folklore is an expression of the human's natural instincts regarding the sonoric. The boundaries of genres are usually blurred; their belonging to a particular type is determined by the singer's inclination and his/her emotional state.

Professional folklore is associated with performing skills. It is the stage of the formation of folklore mechanisms uniting folk traditions, as well as of own schools with their teacher - student position.

The main element of modern folklore is variability, it being a factor of creativity. Art songs, vocal and instrumental ensembles with folk repertoire are among the new genres that appear in musical folklore.

Thus, the overview of the researches in the field of musical art results in the following conclusions:

Firstly, musical folklore is a process of a human's spiritual and moral self-development and a foundation of artistic culture in the system of intercultural communications.

Secondly, it is based on a system of values formed as a result of the natural development of human society as a whole.

Thirdly, the components of musical folklore have informational and sign value, which makes it related to other branches of cultural knowledge.

\section{References}

Aizenshtadt, A.M. (1995). Pesennaia kul'tura evenkov [Song culture of the Evenks]. Krasnoyarsk, Knizhnoe izdatel'stvo, 286 p.

Alekseev, E. (1988). Fol'klor v kontekste sovremennoi kul'tury: rassuzhdeniia o sud'bakh narodnoi pesni [Folklore in the context of modern culture: views on the fate of a folk song]. Moscow, Sovetskii kompozitor, $236 \mathrm{p}$.

Anisimov, S.F. (1988). Dukhovnye tsennosti: proizvodstvo i potreblenie [Spiritual values: production and consumption]. Moscow.

Arkhangel'skii, L.M. (1974). Sotsial'no-eticheskie problemy teorii lichnosti [Socio-ethical problems of personality theory]. Moscow, $165 \mathrm{p}$. 
Asaf'ev, B.V. (1987). O narodnoi muzyke [On folk music]. Leningrad, Muzyka, 248 p.

Avdeeva, Yu.N., Degtyarenko, K.A., Pchelkina, D.S., Shimanskaya, K.I., Koptseva, N.P., Shpak, A.A. (2019a). Religion of the selkups and the kets in the historical and cultural genesis. In Journal of Siberian Federal University. Humanities \& Social Sciences, 12 (5), 726-751.

Avdeeva, Y.N., Degtyarenko, K.A., Koptseva, N.P., Pchelkina, D.S., Shimanskaia, K.I., Shpak, A.A. (2019b). Spetsifika religioznogo soznaniia ketov i sel'kupov v kontekste kul'turnogo i istoricheskogo razvitiia [The specificity of religious consciousness of the Kets and Selkups in the context of cultural and historical development]. In Severnye Arkhivy i Ekspeditsii [Northern Archives and Expeditions], 3 (3), 63-80.

Baudrillard, J. (2008). Simulyakry i simulyaciya [Simulacra and simulation]. Tula.

Chikhacheva, M.M. (2018). Muzykal'naya kul'tura Sibiri: istochniki, tradicionnye i akademicheskie formy tvorchestva [Musical culture of Siberia: sources, traditional and academic forms of creativity]. In Molodoj uchenyj [Young scientist]. Novosibirsk.

Davidovich, V.E. (2013) Kul'turologiya [Culturology]. Sankt-Peterburg. 608 p.

Dil'tey, V. (1980). Ponimaiushchaia psikhologiia [Understanding Psychology]. Moscow, MGU.

Dobrovol'skii, V.N. (1903). Smolenskii etnograficheskii sbornik: chasti 1-4 [Smolensk ethnographic collection of works: parts 1-4]. Sankt-Peterburg, $287 \mathrm{p}$.

Drach, G.V. (2003). Rozhdenie antichnoj filosofii i nachalo antropologicheskoj problematiki [The birth of ancient philosophy and the beginning of anthropological problems]. Moscow.

Eckard, L.D. (2012). Sobiranie fol'klornogo materiala v Krasnoyarskom krae [Collecting folklore material in the Krasnoyarsk territory]. In Kul'tura i iskusstvo sibirskogo goroda: tradicii i sovremennost' [Culture and art of the Siberian city: traditions and modernity]. Krasnoyarsk, 204-207.

Filatov, V.P. (1989). Nauchnoe poznanie i mir cheloveka [Scientific knowledge and the human world]. Moscow.

Habermas J. (1992). K logike social'nyh nauk [To the logic of social Sciences]. In Sovremennaya zapadnaya teoreticheskaya sociologiya [Modern Western theoretical sociology]. Moscow, 29-56 p.

Hippius, E.V. (2003). Melodicheskii sklad, myslimyi vne garmonii i taktovoi ritmiki, i melodicheskii sklad, garmonicheski oposredovannyi [Melodic texture, conceivable out of harmony and bar rhythm, and melodic texture, harmoniously mediated]. In Materialy $i$ stat' $i$ : $k$ 100-letiiu so dnia rozhdeniia E.V. Gippiusa. Sostaviteli: E.A. Dorokhova, O.A. Pashina [Materials and articles: to the 100th anniversary of E.V. Gippius's birth. Compiled by E.A. Dorokhov, O.A. Pashin]. Moscow.

Iaremenko, S.N. (1997). Vneshnost' cheloveka v kul'ture [Appearance of a person in culture]. Rostov, $172 \mathrm{p}$.

Kagan, M.S. (1997). Filosofskaia teoriia tsennosti [Philosophical Theory of Value]. Sankt-Peterburg.

Kistova, A.V., Pimenova, N.N., Reznikova, K.V., Sitnikova, A.A., Kolesnik, M.A., Khudonogova, A.E. (2019). Religion of Dolgans, Nganasans, Nenets and Enets. In J. Sib. Fed. Univ. Humanit. soc. sci., 12(5), 791-811. DOI: 10.17516/1997-1370-0424.

Klimova, S.G. (1996). Izmeneniia tsennostnykh osnovanii identifikatsii [Changes in the value bases of identification]. In Sotsiologicheskie issledovaniia [Sociological studies], (1).

Kolesnik, M.A. (2014). Obzor izucheniia fol'klora korennykh narodov Severa [A review of the studies of folklore of the indigenous peoples of the North]. In Litera, (3), 39-59.

Kolesnik, N.M., Libakova, N.M., Sertakova, E.A. (2018). Art education as a way of preserving the traditional ethnocultural identity of indigenous minority peoples from the North, Siberia and the Far East. In Science for education, 8 (4), 233-247.

Koptseva, N.P. (2014). Ekspertnyi analiz osnovnykh tendentsii ekonomicheskogo razvitiia korennykh malochislennykh narodov Severnoi Sibiri [Expert analysis of the main trends in the economic development of the indigenous peoples of Northern Siberia]. In Economic Annals-XXI, 11-12, 93-96.

Krymguzhina, Z.Z. (2017). Narodnaia muzyka kak faktor vospitaniia dukhovnosti uchashchikhsia $\mathrm{v}$ sisteme obshchego muzykal'nogo obrazovaniia [Folk music as a factor of the students' spirituality formation in the system of general musical education]. In Teoreticheskie i prakticheskie aspekty psikhologii: Monografiia [Theoretical and practical aspects of psychology: Monograph]. Moscow, 53-74. 
Lapin, V.A. (1987). Muzykal'naia kul'tura narodov [Musical culture of the peoples]. Moscow, $267 \mathrm{p}$.

Leont'ev, D.A. (1996). Tsennost' kak mezhdistsiplinarnoe poniatie: opyt mnogomernoi rekonstruktsii [Value as an interdisciplinary concept: practice of multidimensional reconstruction]. In Voprosy filosofii [Philosophy Issues], (4).

Libakova, N.M., Sertakova, E.A. (2018). Ekspeditsiia v poselok Surinda Evenkiiskogo munitsipal'nogo raiona. Dnevnik polevogo issledovaniia [Expedition to the village of Surinda in the Evenk municipal district. Field research diary]. In Severnye Arkhivy i Ekspeditsii [Northern Archives and Expeditions], 2 (2), 6-29.

Libakova, N.M., Kolesnik, M.A., Sertakova, E.A. (2017). Issledovatel'skie vozmozhnosti antropologii iskusstva na primere kostoreznykh proizvedenii masterov Sibiri [Research opportunities for art anthropology on the example of bone carving works of Siberian masters]. In Sibirskii antropologicheskii zhurnal [Siberian Anthropological Journal], 1 (01), 22-34.

Mates, T.P. (2016). Ob “yasnenie, ponimanie, interpretaciya [Explanation, understanding, interpretation]. Rostov, $102 \mathrm{p}$.

Middendorf, A.F. (1965). Ocherki po istorii russkoi etnografii, fol'kloru i antropologii [Essays on the history of Russian ethnography, folklore and anthropology]. Moscow, $220 \mathrm{p}$.

Nevolko, N.N. (2011). The historiographical review of the scientific literature of the late XIX to the first decade of the XXI century concerning the problem of ethnic identification of the Khakass ethnos. In Journal of Siberian Federal University. Humanities \& Social Sciences, 6 (4), 823-836.

Petrov, M.K. (2004) YAzyk, znak, kul'tura [Language, sign, culture]. Moscow, 328 p.

Podoprigora, S.Ia. (2015). Filosofskij ocherk o prirode cheloveka [Philosophical essay on human nature]. Moscow.

Rezhabek E.Ia. (2002). Stanovlenie mifologicheskogo soznaniya i ego kognitivnosti [Formation of mythological consciousness and its cognition]. In Voprosy filosofii [Question of philosophy]. Moscow, 52-66.

Reznikova, K.V., Pimenova, N.N., Kistova, A.V., Kolesnik, M.A., Koptseva, N.P., Sitnikova, A.A., Seredkina, N.N., Zamaraeva, Yu.S., Petrova, K.I. (2019). Ethnocultural space of Krasnoyarsk Krai: the current state. In J. Sib. Fed. Univ. Humanit. soc. sci., 12 (8), 1552-1567. DOI: 10.17516/1997-1370-0464.

Rikkert, G. (1914). O sisteme tsennostey [On the system of values]. Moscow.

Rikkert, G. (1998). Tsennost' i deistvitel'nost' [Value and Reality]. In Filosofiia zhizni [Philosophy of Life]. Kiev.

Sheikin, Iu.I. (2002). Istoriia muzykal'noi kul'tury narodov Sibiri: Sravnitel'no-istoricheskie issledovaniia [History of the musical culture of the peoples of Siberia: Comparative historical research]. Rossiiskaia akademiia nauk. Sibirskoe otdelenie. Institut problem malochislenykh narodov Severa [i dr.], Moscow.

Shimanskaia, K.I., Koptseva, N.P. (2018). Istoriograficheskii obzor korennykh issledovanii za 20142018 gg. [Historiographic review of indigenous research for 2014-2018]. In Sibirskii antropologicheskii zhurnal [Siberian Journal of Anthropology], 2 (01), 43-57.

Shopengauer, A. (1969). Bol'shaia Sovetskaia Entsiklopediia [The Great Soviet Encyclopedia]. Moscow, $367 \mathrm{p}$.

Shternberg, L.Ia. (1936). Pervobytnaia religiia $v$ svete etnografii [Primitive religion in the light of ethnography]. Leningrad.

Shtompel, O.M. (2009). Kul'turologiya: poisk metodologicheskoj paradigm [Cultural studies: the search for methodological paradigm]. In Fundamental'nye problemy kul'turologii [Fundamental problems of cultural studies]. Sankt-Peterburg, Ejdos, 188-193 p.

Sokhor, A.N. (1975). Sotsiologiia i muzykal'naia kul'tura [Sociology and musical culture]. Leningradskii gosudarstvennyi institut teatra, muzyki i kinematografii, Moscow, Sovetskii kompozitor, 202 p.

Sokolov, A.V. (2010). Filosofiya informacii [Philosophy of information]. Sankt-Peterburg.

Sorokin, P.A. (1992). Chelovek. Tsivilizatsiia. Obshchestvo [Human. Civilization. Society]. Moscow. 
Suslov, I.M. (1928). Social'naya kul'tura tungusov bassejna Podkamennoj Tunguski [The social culture of the Tungus basin of the Podkamennaya Tunguska river]. In Severnaya Aziya [Northern Asia]. Moscow, $178 \mathrm{p}$.

Tolstoy, I.I. (1966). Stat'i o fol'klore [Articles on folklore]. AN SSSR, Moscow, Izdatel'stvo "Nauka", $249 \mathrm{p}$.

Vasilenko, V.A. (1966). Value and value relationships, In Problema tsennostei v filosofii [The problem of values in philosophy]. Moscow, Leningrad.

Vasilevich, G.M. (1969). Istoriko-etnograficheskie ocherki (XVIII-nachalo XX vv.) [Historical and ethnographic essays (XVIII - beginning of XX centuries)]. Moscow, $346 \mathrm{p}$.

Vinogradov, G.S. (2009). Etnografiya detstva i russkaya narodnaya kul'tura $v$ Sibiri [Ethnography of childhood and Russian folk culture in Siberia]. Moscow.

Volkov, G.N. (1976). Narodnyye traditsii sibirskogo naroda [Folk traditions of the Siberian people]. Moscow, $57 \mathrm{p}$.

Voskoboinikov, M.G. (1980). Sibirskii fol'klor [Siberian folklore]. Novosibirsk, 170 p.

Yung, K.G. (1991). Arhetip i simvol [Archetype and symbol]. Moscow, 304 p.

Zamaraeva, Yu.S., Luzan, V.S., Metlyaeva, S.V., Seredkina, N.N., Koptseva, N.P., Fil'ko, A.I., Khrebtov, M.Ya. (2019). Religion of the Evenki: history and modern times. In Journal of Siberian Federal University. Humanities \& Social Sciences, 12 (5), 853-871.

Zakovorotnaia, M.V. (1999) Identichnost' cheloveka. Social'no-filosofskie aspekty [The identity of a person. Social and philosophical aspects]. Rostov.

Zemtsovskii, I.I. (1977). Narodnaia muzyka i sovremennost': (K probleme opredeleniia fol'klora) [Folk music and modernity: (On the problem of folklore determination)]. In Sovremennost' i fol'klor [Modernity and Folklore], Moscow, $56 \mathrm{p}$.

Zemtsovskii, I.I. (1978). Fol'klor i kompozitor [Folklore and composer]. Moscow, 174 p.

Zhdanov, Iu.A. (2005). Problemy teorii i istorii kul'tury [Problems of theory and history of culture]. Rostov, 428 p.

Zlobin, N.S. (1980). Kul'tura i obshchestvennyj progress [Culture and social progress]. Moscow, 303p. 


\section{Ценностные ориентиры коренных}

малочисленных народов Красноярского края

в музыкальном фольклоре: обзор исследований

\section{С.В.Березюк, М.Я. Хребтов \\ Сибирский федеральный университет}

Российская Федерачия, Красноярск

Аннотация. В настоящей статье представлены результаты анализа музыкального фольклора в ракурсе культурологического знания. Цель анализа была связана с определением ценностных ориентиров в понимании феномена музыкального фольклора. Для аналитического обзора данной тематики выбран сравнительный и типологический методы исследования. На основании проведенного анализа сделаны выводы об особенностях музыкального фольклора в его историческом и культурном развитии. Его результаты установили главное предназначение рассматриваемого явления в его ценностной ориентации. Обнаружено, что музыкальный фольклор есть одна из областей музыкального искусства. Он имеет собственное духовное пространство и раскрывает некоторые особенности культурологического знания. Полученные данные могут быть применены для дальнейшего изучения народностей других регионов России.

Ключевые слова: музыкальный фольклор, ценностная ориентация, ценности, общество, народ, культура, этнос.

Исследование выполнено при финансовой поддержке РФФИ в рамках научного проекта № 19-39-90016. Исследование выполнено при финансовой поддержке РФФИ в рамках научного проекта № 19-39-90017.

Научная специальность: 24.00.00 - культурология. 